\title{
Cytotoxic Effects of Native and Recombinant Frutalin, a Plant Galactose-Binding Lectin, on HeLa Cervical Cancer Cells
}

\author{
Carla Oliveira, Ana Nicolau, José A. Teixeira, and Lucília Domingues \\ Institute for Biotechnology and Bioengineering (IBB), Centre of Biological Engineering, University of Minho, Campus de Gualtar, \\ 4710-057 Braga, Portugal \\ Correspondence should be addressed to Lucília Domingues, luciliad@deb.uminho.pt
}

Received 25 February 2011; Revised 17 August 2011; Accepted 17 August 2011

Academic Editor: M. Piacentini

Copyright (๑) 2011 Carla Oliveira et al. This is an open access article distributed under the Creative Commons Attribution License, which permits unrestricted use, distribution, and reproduction in any medium, provided the original work is properly cited.

Frutalin is the $\alpha$-D-galactose-binding lectin isolated from breadfruit seeds. Frutalin was obtained from two different sources: native frutalin was purified from its natural origin, and recombinant frutalin was produced and purified from Pichia pastoris. This work aimed to study and compare the effect of native and recombinant frutalin on HeLa cervical cancer cells proliferation and apoptosis. Furthermore, the interaction between frutalin and the HeLa cells was investigated by confocal microscopy. Despite having different carbohydrate-binding affinities, native and recombinant frutalin showed an identical magnitude of cytotoxicity on HeLa cells growth $\left(\mathrm{IC}_{50} \sim 100 \mu \mathrm{g} / \mathrm{mL}\right.$ ) and equally induced cell apoptosis. The interaction studies showed that both lectins were rapidly internalised and targeted to HeLa cell's nucleus. Altogether, these results indicate that frutalin action is not dependent on its sugar-binding properties. This study provides important information about the bioactivity of frutalin and contributes to the understanding of the plant lectins cytotoxic activity.

\section{Introduction}

Lectins are a well-known group of carbohydrate-binding proteins that mediate a variety of biological processes and can be found in different organisms, namely, plants, animals, viruses, and microorganisms [1]. Plant lectins demonstrated in the end of the 1960s the ability to specifically agglutinate malignant transformed cells, early indicating that cancer is associated with a change in cell surface sugars, which led to their intensive application to cancer research [2]. Since then, some plant lectins have been found to possess remarkable anticancer properties in in vivo, in vitro, and in human case studies and have also been successfully adopted for alternative cancer therapy [3-5]. Plant lectins cause cytotoxicity in cancer cells via different mechanisms depending on the lectin, namely, by inducing apoptosis, autophagy, or necrosis and inhibiting cells growth, preferentially binding to cancer cells membrane or their receptors [6]. After this recognition step, lectins can either remain on cells surface or be internalised into the cells and located in different compartments [7].

Apoptosis (self-killing) and autophagy (self-eating) are different types of programmed cell death (Type I and
II, resp.), while necrosis is a form of cell death with an unregulated or unscheduled process [6]. The biochemical events that occur during apoptosis lead to several typical morphological cell changes. These changes include blebbing, loss of cell membrane asymmetry and attachment, cell shrinkage, nuclear fragmentation, chromatin condensation, and chromosomal DNA fragmentation [8]. Autophagy differs of apoptosis as it is independent of phagocytosis and is characterised by the presence of autophagosomes, autolysosomes, and an intact nucleus, although they may be interconnected [9]. Programmed cell death is an encoded suicide program, which allows the elimination of cells that have been produced in excess, developed improperly, or have sustained genetic damage. It has been recognised as an ideal strategy for cancer chemotherapy [10]. Therefore, lectins capable of inducing such natural mechanism may be used potentially as anticancer agents.

This study aims at investigating the cytotoxicity of frutalin, the $\alpha$-D-galactose-binding jacalin-related lectin isolated from Artocarpus incisa seeds (breadfruit plant) [11], on human cancer cells in vitro. Studies on the strong immunomodulatory activity of frutalin (stimulation of the immune 
system), both in vitro and in vivo, have been reported, but the effects on cancer cells have never been investigated $[12,13]$. In spite of its potential biomedical application, the use of frutalin isolated from its natural source has several drawbacks, such as the time dispended in purification, the extraction yield, and the heterogeneity of pure frutalin samples due to the presence of different isoforms. These isoforms consist in slightly different amino acid sequences having, or not, different glycosylation places and extensions that may confer distinct biological properties and lead to an undesired variability of results when applied as a biomedical tool [14]. To overcome these limitations, frutalin with a defined amino acid sequence was expressed and produced in the Pichia pastoris expression system [15]. The ability of this recombinant frutalin and native frutalin to bind human tumour cells has recently been demonstrated [16, 17]. Moreover, recombinant frutalin showed higher capacity than native frutalin to differentiate malignant from nonmalignant cells in immunohistochemical studies conducted with human prostate tissues [16].

In this work, the cytotoxicity of native frutalin and its recombinant form produced in $P$. pastoris on the proliferation of HeLa cervical cancer cells is studied and compared. Moreover, the cell death mechanism induced by both lectin forms and their localisation on cancer cells are investigated. To our knowledge, this is the first time that the interaction between a plant lectin and HeLa cells is studied by confocal microscopy.

\section{Materials and Methods}

2.1. Production and Purification of Native Frutalin and Recombinant Frutalin. Native frutalin was purified from Artocarpus incisa seeds by affinity chromatography on Adenanthera pavonina cross-linked galactomannan as previously described [11]. The production and purification of recombinant frutalin in the Pichia pastoris expression system has been previously reported [15]. Native frutalin (n-frutalin) and recombinant frutalin ( $r$-frutalin) in PBS buffer were concentrated to the desired final concentration in $10 \mathrm{kDa}$ Amicon tubes (Millipore). The concentration of the two lectins was estimated from the absorbance at $280 \mathrm{~nm}\left(\varepsilon_{\text {frutalin }}=27390 \mathrm{M}^{-1} \mathrm{~cm}^{-1}\right)$. Lectins were sterilised by filtration trough $0.2 \mu \mathrm{m}$ pore size filters.

2.2. Cell Culture. In vitro assays were performed using HeLa cells (originated from human cervical cancer) grown at $37^{\circ} \mathrm{C}$, in a $95 \%$ humidified air containing $5 \% \mathrm{CO}_{2}$, in $25 \mathrm{~cm}^{3}$ T-flasks (Orange) containing Dulbecco's modified Eagle's media (DMEM) supplemented with 10\% of bovine fetal serum (FBS) (Invitrogen) and $1 \mu \mathrm{g} / \mathrm{mL}$ penicillin/streptomycin (Sigma). The cells were fed every 2-3 days, and at confluency they were harvested with $0.05 \%$ (w/v) trypsin-EDTA (Sigma) and subcultivated in identical medium.

2.3. MTS Assay. HeLa cells were seeded at $5 \times 10^{3}$ cells per well into 96-well plates and allowed to adhere for
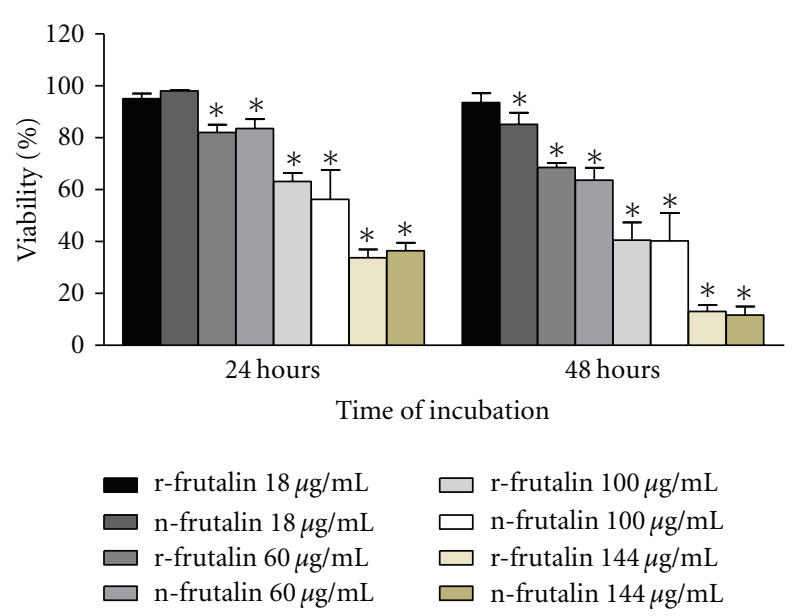

FIGURE 1: Effect of different concentrations of $\mathrm{n}$-frutalin and $\mathrm{r}$ frutalin on HeLa cells proliferation at 24 and $48 \mathrm{~h}$. Each time point is shown as mean \pm SEM of at least 3 replicates $(n=3) ;{ }^{*} P<$ 0.05 . No statistically significant differences were observed in terms of toxicity between the same concentrations of recombinant and native frutalin, regardless of concentration and time point analysed.

$24 \mathrm{~h}$ at $37^{\circ} \mathrm{C}, 5 \% \mathrm{CO}_{2}$. After that, culture medium was decanted and replaced with fresh culture medium, and various concentrations of $\mathrm{n}$-frutalin or $\mathrm{r}$-frutalin (ranging from 18 to $144 \mu \mathrm{g} / \mathrm{mL}$ ) were added to the wells in triplicate. Then, plates were incubated for 24 or $48 \mathrm{~h}$ at $37^{\circ} \mathrm{C}, 5 \%$ $\mathrm{CO}_{2}$. For the recovery assays, cells were incubated with nfrutalin or $\mathrm{r}$-frutalin for $24 \mathrm{~h}$; then the culture medium was decanted and replaced with fresh culture medium, and cells were incubated for an additional $24 \mathrm{~h}$ in the absence of the lectins.

Cell viability after lectin treatment was quantified by the MTS assay (3-(4, 5-dimethylthiazol-2-yl)-5-(3-carboxylmethoxyphenyl)-2-(4-sulfophenyl)-2H-tetrazolium), a colorimetric assay that provides a measure of the mitochondrial metabolic activity, as follows. The culture medium of each well was decanted and replaced with $100 \mu \mathrm{L}$ of fresh culture medium. Then $20 \mu \mathrm{L}$ of "CellTiter 96 AQueous One Solution Reagent" (Promega) were added into each well, and plates were incubated for $2 \mathrm{~h}$ at $37^{\circ} \mathrm{C}, 5 \% \mathrm{CO}_{2}$. The amount of soluble formazan produced by cellular reduction of the MTS was measured at $490 \mathrm{~nm}$. The results obtained were compared to a control prepared in the same conditions but with the addition of PBS buffer instead of the lectins (the control was taken as $100 \%$ of cell growth). BSA was used as protein control, and at least three independent experiments were performed. The results were statistically analysed using two-way ANOVA and Bonferroni test for postcomparison tests using GraphPadPrism software (GraphPad, USA).

2.4. Observation of Cellular Morphologic Changes. The incubation of HeLa cells with $\mathrm{n}$-frutalin and $\mathrm{r}$-frutalin was done as described for the MTS assay. The cultures were observed and photographed at an inverted light microscope (Leica DMIL), either with or without trypan blue staining. For trypan blue staining, culture medium was removed, and cells 


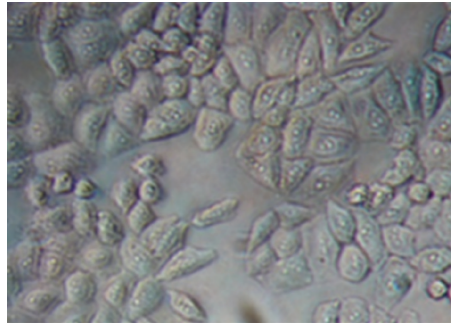

(a)

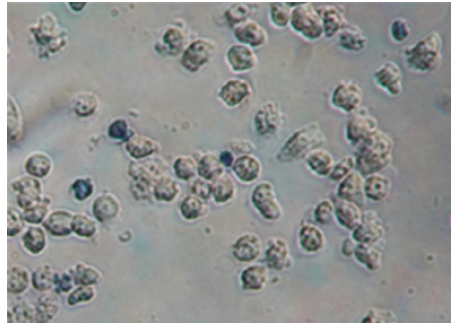

(b)

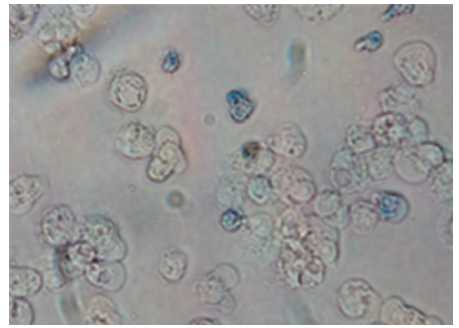

(c)

FIGURE 2: Trypan blue staining of HeLa cells grown in the absence (a) and presence of $\mathrm{n}$-frutalin (b) and $\mathrm{r}$-frutalin (c) (both at $100 \mu \mathrm{g} / \mathrm{mL})$ for $48 \mathrm{~h}$ (original magnification of $\times 200$ ).
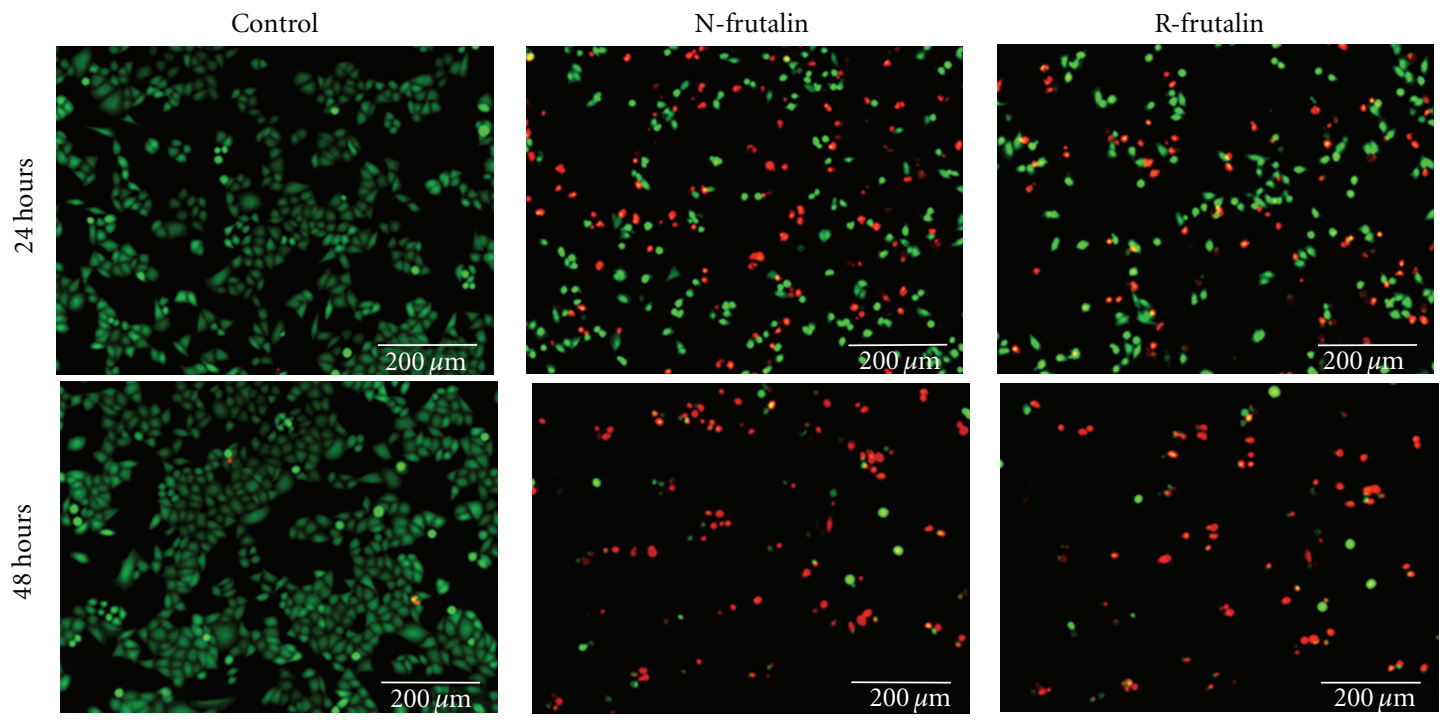

FIGURE 3: Effect of n-frutalin and r-frutalin on HeLa cells viability. Merged fluorescence photographs for the viability evaluation of HeLa cells cultured for 24 and $48 \mathrm{~h}$ in the presence of $\mathrm{n}$-frutalin and $\mathrm{r}$-frutalin (both at $100 \mu \mathrm{g} / \mathrm{mL}$ ) using the LIVE/DEAD Viability/Cytotoxicity Kit for mammalian cells are shown. In the control, cells were incubated with PBS buffer instead of the lectins. Live cells are stained in green, and dead cells are stained in red.

were directly stained inside wells for 15 min with $0.4 \%(\mathrm{w} / \mathrm{v})$ trypan blue solution (Sigma) diluted $1: 2$ in PBS and then washed two times with this buffer.

\subsection{Live and Dead Assay. The "LIVE/DEAD Viability/Cyto-} toxicity Kit for mammalian cells" (Invitrogen) was used to determine cell viability. This kit provides a two-colour fluorescence cell viability assay, based on the simultaneous determination of the live and dead cells with two probes that measure intracellular esterase activity (live cells) and plasma membrane integrity (dead cells). For that, HeLa cells were seeded at $5 \times 10^{5}$ cells per well into 6-well plates and allowed to adhere for $24 \mathrm{~h}$ at $37^{\circ} \mathrm{C}, 5 \% \mathrm{CO}_{2}$. Thereafter, culture medium was decanted and replaced with fresh culture medium, and $100 \mu \mathrm{g} / \mathrm{mL}$ of $\mathrm{n}$-frutalin or $\mathrm{r}$ frutalin were added to the respective wells. A negative control was prepared by adding PBS buffer to the cells instead of the lectins. Plates were incubated for an additional 24 or $48 \mathrm{~h}$ period at $37^{\circ} \mathrm{C}, 5 \% \mathrm{CO}_{2}$, and then the LIVE/DEAD assay was conducted, following manufacturer instructions.
Cells were observed at a fluorescence microscope Olympus BX51, and the images were acquired with a colour camera Olympus DP71 using the B-Cell software (Olympus). Three independent experiments were performed.

2.6. DNA Fragmentation Analysis. HeLa cells $\left(2 \times 10^{6}\right)$ were cultured in $25 \mathrm{~cm}^{3}$ T-flasks for $24 \mathrm{~h}$ at $37^{\circ} \mathrm{C}, 5 \% \mathrm{CO}_{2}$. Then, culture medium was complemented with $100 \mu \mathrm{g} / \mathrm{mL}$ of nfrutalin, $r$-frutalin, or the equivalent volume of PBS, and cells were cultured for an additional $24 \mathrm{~h}$ period. Thereafter, cells were harvested and suspended in $2 \mathrm{~mL}$ of culture medium. Total DNA was isolated using the kit "DNeasy Blood \& Tissue Handbook" (Qiagen), analysed by electrophoresis on 1\% (w/v) agarose gels containing $0.1 \mu \mathrm{g} / \mathrm{mL}$ ethidium bromide and visualized under UV light.

2.7. TUNEL Assay. HeLa cells $\left(5 \times 10^{4}\right)$ were cultured on plastic coverslips (Sarstedt), inside 24-well plates, and treated with $\mathrm{n}$-frutalin, $\mathrm{r}$-frutalin, or PBS as described for the live 


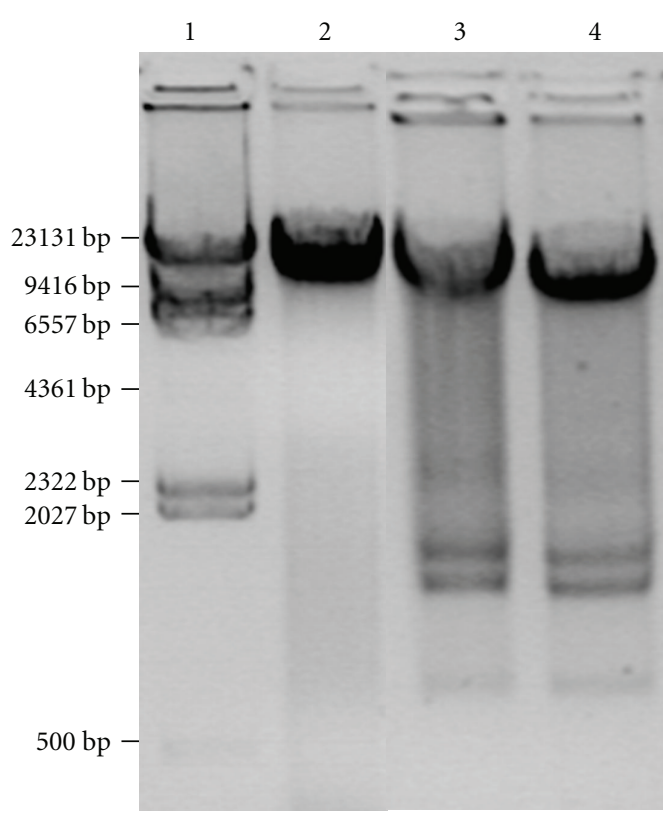

Figure 4: Analysis on 1\% (w/v) agarose gel of HeLa genomic DNA profiling. Legend: (1) $\lambda /$ HindIII molecular weight marker; (2) genomic DNA of untreated cells; (3) and (4) genomic DNA of cells treated for $24 \mathrm{~h}$ with $\mathrm{n}$-frutalin and $\mathrm{r}$-frutalin (both at $100 \mu \mathrm{g} / \mathrm{mL}$ ), respectively.

and dead assay. After that, the TUNEL assay (Terminal deoxynucleotidyl transferase-mediated deoxyuridine triphosphate nick-end labelling), which examines DNA strand breaks during apoptosis, was performed using the "In Situ Cell Death Detection kit, Fluorescein" (Roche Diagnostics), according to the manufacturer instructions, followed by fluorescence microscopy (staining cells-green). To identify total nucleus, cells were also stained with DAPI (staining nucleus-blue). The percentage of TUNEL-stained nuclei was determined in relation to every DAPI-stained nuclei observed, at a 200x magnification field. One thousand nuclei were evaluated, and three independent experiments were performed.

\subsection{Fluorescence Staining and Confocal Microscopy. Confocal} microscopy was conducted to determine the localisation of $\mathrm{n}$-frutalin and r-frutalin on HeLa cells. First, HeLa cells were cultured as described for the TUNEL assay. Then, cells were incubated for $1 \mathrm{~h}$ at $37^{\circ} \mathrm{C}, 5 \% \mathrm{CO}_{2}$, with $12 \mu \mathrm{g} / \mathrm{mL}$ of $\mathrm{n}$-frutalin or $92 \mu \mathrm{g} / \mathrm{mL}$ of $\mathrm{r}$-frutalin labelled with FITC (fluorescein isothiocyanate). The difference between $n$ - and r-frutalin concentrations is due to the difference of the FITC content in each of the frutalin conjugated forms and aims at the normalization of the fluorescence signal. The labelling of the two lectins with FITC was performed as comprehensibly described by Sahasrabuddhe et al. [18]. After incubation, cells were washed twice with PBS and fixed for $10 \mathrm{~min}$ with ice-cold methanol. Finally, cells were stained with DAPI to identify the nucleus. Images were acquired in a sequential mode by Confocal Scanning Laser Microscope OLYMPUS BX61/FLUOVIEW1000, using a 60x oil immersion objective and the specific filter settings for DAPI and FITC. This experiment was repeated two times for each lectin.

\section{Results}

3.1. Effect of N-Frutalin and R-Frutalin on HeLa Cells Growth. The effect of $\mathrm{n}$-frutalin and r-frutalin on HeLa cancer cells growth was assessed through the determination of the metabolic activity by the MTS colorimetric assay. The biomolecular properties of $n$-frutalin and $r$-frutalin are presented in Table 1.

In order to evaluate the effect of $n$-frutalin and $r$ frutalin dosage on HeLa cells viability, various random concentrations (ranging from 18 to $144 \mu \mathrm{g} / \mathrm{mL}$ ) were incubated with these cells for two different periods of time (24 and $48 \mathrm{~h}$ ) (Figure 1). N-frutalin and r-frutalin showed to affect negatively HeLa cells proliferation in almost all concentrations tested. The magnitude of this effect was directly proportional to the dosage, as cell viability decreased with increasing lectin concentrations. Moreover, for the same lectin concentration, cell viability decreased over incubation time. The lowest cell viability value was obtained after $48 \mathrm{~h}$ of incubation with $144 \mu \mathrm{g} / \mathrm{mL}$ of $\mathrm{n}$-frutalin (11.6\%). BSA, in the same concentration range as the lectins, did not have any effect on HeLa cells growth.

As shown in Figure 1, similar concentrations of nfrutalin and r-frutalin yielded identical magnitude of cytotoxicity on HeLa cells. No statistically significant differences were found. When HeLa cells were incubated for $24 \mathrm{~h}$ with $100 \mu \mathrm{g} / \mathrm{mL}$ of $\mathrm{n}$-frutalin or $\mathrm{r}$-frutalin, cell viability was about $56 \%$ and $63 \%$, respectively, comparing to control, while $48 \mathrm{~h}$ of incubation reduced cell viability for, at least, $40 \%$. Thus, $24 \mathrm{~h}$ of incubation of HeLa cells with about $100 \mu \mathrm{g} / \mathrm{mL}$ of frutalin is sufficient for half inhibition of cells growth $\left(\mathrm{IC}_{50}\right)$. This concentration was used in subsequent assays, unless stated otherwise.

HeLa cells did not recover when $n$-frutalin or $r$-frutalin were removed from the culture medium, since no further proliferation was observed in the following $24 \mathrm{~h}$ of incubation in the absence of the lectins (data not shown). This result indicates that the cytotoxic effect of $n$-frutalin and $r$-frutalin on HeLa cells is irreversible.

3.2. Effect of N-Frutalin and R-Frutalin on HeLa Cells Morphology. The growth and morphology of HeLa cells during incubation with $\mathrm{n}$-frutalin and $\mathrm{r}$-frutalin $(100 \mu \mathrm{g} / \mathrm{mL})$ was monitored by microscopy. After the addition of the lectins, alterations on morphology and a decrease in the cell number were detected by visual inspection, and it reached a maximum after two days of incubation. Light microscopy photographs in Figure 2 show HeLa cells grown for $48 \mathrm{~h}$ in the absence (negative control) or presence of $\mathrm{n}$-frutalin and r-frutalin. As it can be seen, the cells in the control wells proliferated normally, reached confluency, and presented the typical morphology - they were flattened and spread. No signs of cells death and growth disorders were observed in these wells. On the other hand, in the wells where lectins were added, the morphology of the cells was completely different; they got round and appeared as if they were 


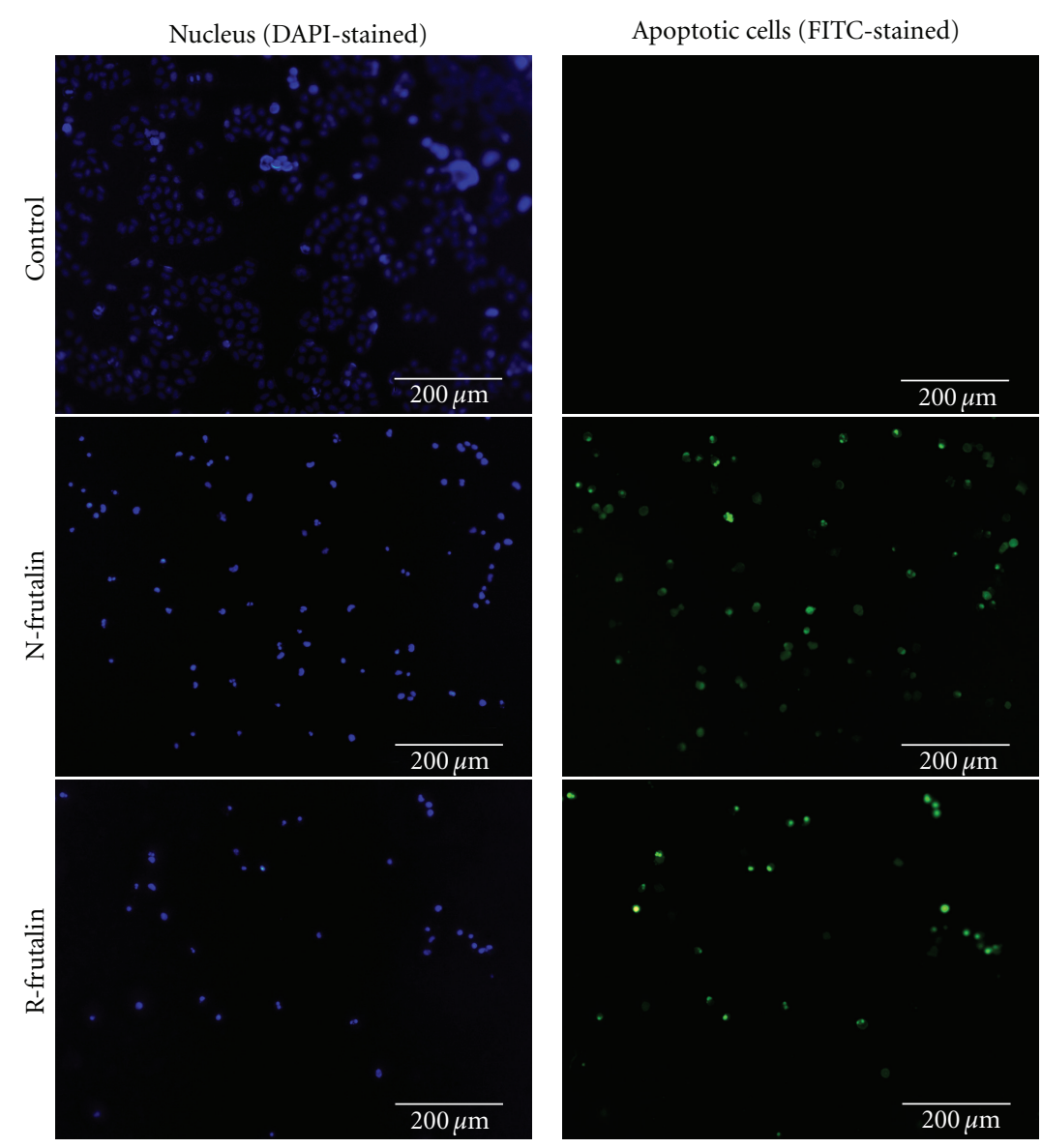

FIGURE 5: Apoptosis-inducing activity analysis by TUNEL assay. Fluorescence photographs of HeLa cells treated with n-frutalin and r-frutalin (both at $100 \mu \mathrm{g} / \mathrm{mL}$ ) for $24 \mathrm{~h}$ and analysed by TUNEL assay are shown. In the control, cells were incubated with PBS buffer instead of the lectins.

TABLE 1: Biomolecular properties of frutalin extracted from breadfruit seeds (A. incisa) ( $\mathrm{n}$-frutalin) and recombinant frutalin produced in P. pastoris (r-frutalin).

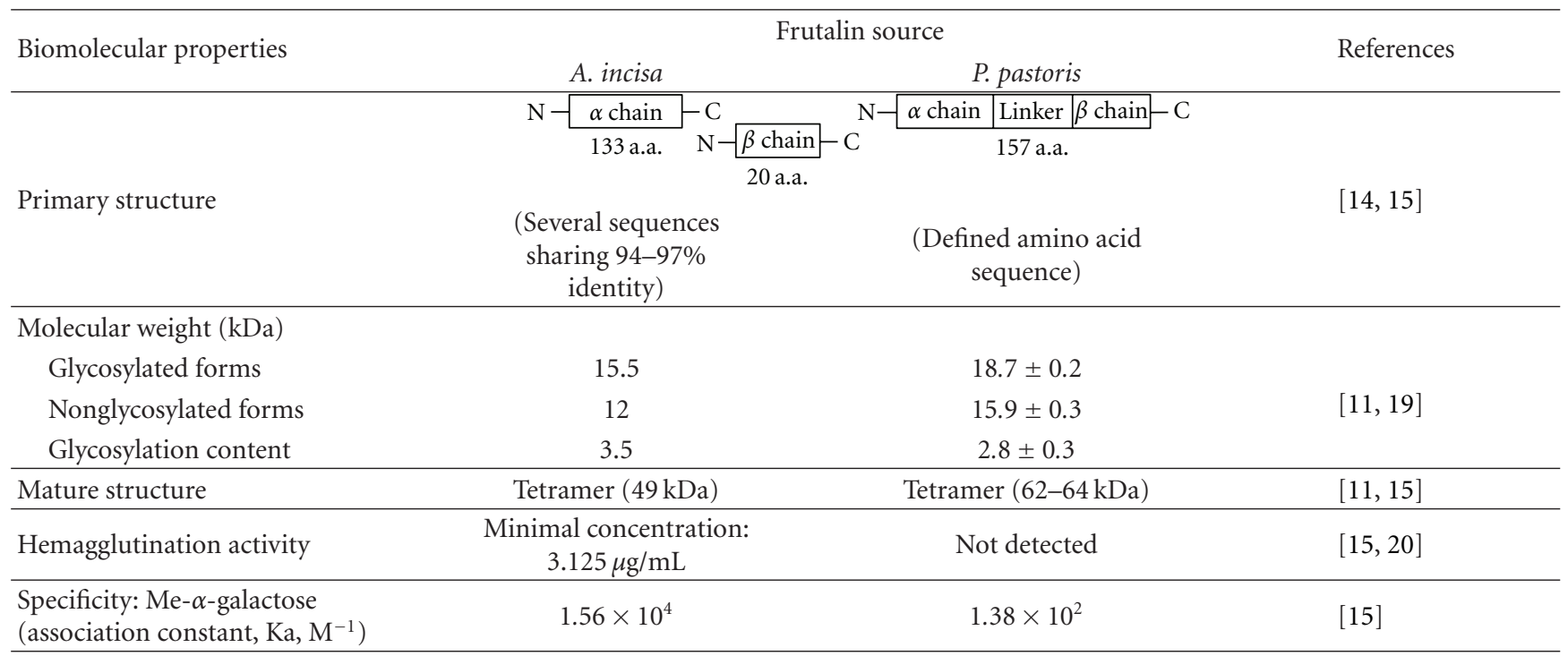



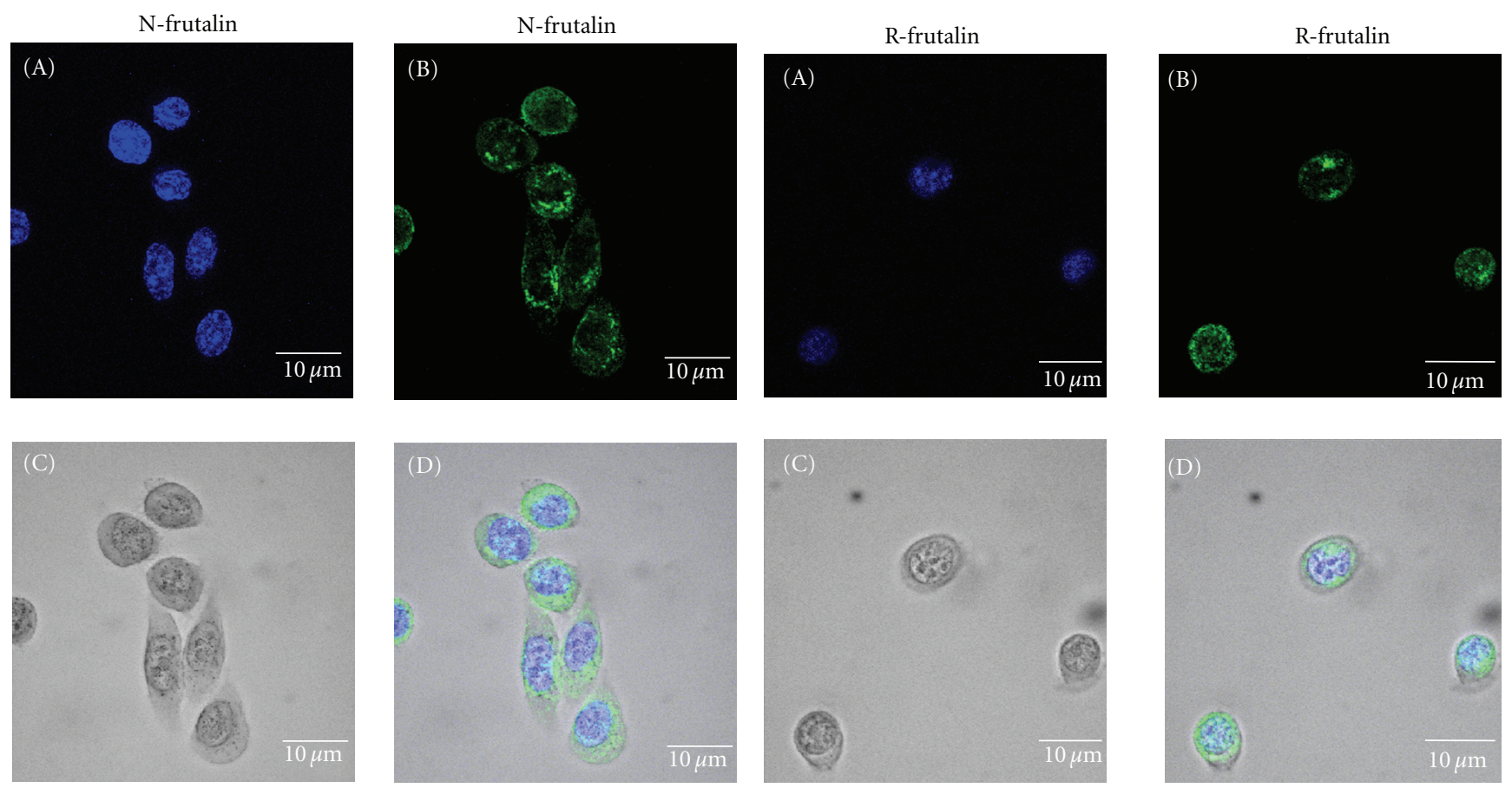

FIGURE 6: Localisation of $\mathrm{n}$-frutalin and $\mathrm{r}$-frutalin in HeLa cells by fluorescence confocal microscopy. Representative projections for the cellular localisation of each frutalin form in HeLa cells $1 \mathrm{~h}$ after incubation at $37^{\circ} \mathrm{C}$ are shown: $\mathrm{n}$-frutalin - projection of 38 slices of 50 in the total; r-frutalin-projection of 13 slices of 25 in the total. Legend: (A) nuclear staining with DAPI; (B) lectin staining with FITC; (C) bright field; (D) merged images.

without substrate. In addition, the number of cells was far inferior to the number of cells in the control wells, and many cellular debris were observed. In order to verify cell death, cells were stained with trypan blue. In the control wells, few cells turned blue, but several cells treated with $\mathrm{n}$-frutalin and $r$-frutalin showed a strong blue staining, indicating cell death. The images in Figure 2 show that $\mathrm{n}$-frutalin and $\mathrm{r}$-frutalin induce cancer cells death; nevertheless, these results were further confirmed in the LIVE/DEAD assay.

\subsection{Effect of N-Frutalin and R-Frutalin on HeLa Cells Viabil- ity. LIVE/DEAD assay was performed to ensure that HeLa cells were dead after the treatment with $\mathrm{n}$-frutalin and $\mathrm{r}$ - frutalin. The fluorescence images in Figure 3 unequivocally show that $\mathrm{n}$-frutalin and $\mathrm{r}$-frutalin cause HeLa cells death. It can be noticed that, in the control wells (no lectins added), all cells were alive (stained in green) and no dead cells were observed (stained in red), while in the wells where lectins were added the situation was the opposite; in those wells, several dead cells and a significant reduction in the total cell number were observed. The extent of this negative effect was directly proportional to the incubation time. It can also be deduced from Figure 3 that $\mathrm{n}$-frutalin and $\mathrm{r}$-frutalin yielded similar cell dead magnitude, both at 24 and $48 \mathrm{~h}$, which corroborate the MTS assay (Figure 1).}

\subsection{Apoptosis-Inducing Activity of N-Frutalin and R-Frutalin.} To investigate the apoptosis-inducing activity of $n$-frutalin and r-frutalin on HeLa cells, the integrity of the genomic
DNA of lectin-treated cells was analysed by agarose gel electrophoresis and by the TUNEL assay. If death is due to apoptosis it is expected to detect degradation of genomic DNA in dying cells. As shown in Figure 4, no degradation of genomic DNA extracted from HeLa cells control (no lectins added) was observed on the agarose gel (line 2), but the genomic DNA from cells grown in the presence of $\mathrm{n}$-frutalin or $\mathrm{r}$-frutalin showed some degradation (lines 3 and 4), indicating therefore the occurrence of apoptosis. Nevertheless, it should be noted that the presence of dead cells may also contribute to the spread of DNA in Figure 4.

The TUNEL assay was conducted to further confirm that cell death occurred by apoptosis. This assay is a highly sensitive immunostaining procedure designed to detect free $3^{\prime}-\mathrm{OH}$ single-strand DNA breaks produced by DNA fragmentation, typically localised to cells undergoing programmed cell death. The fluorescence images in Figure 5 show that $\mathrm{n}$-frutalin and $\mathrm{r}$-frutalin induced apoptosis on HeLa cells (green stained cells). Moreover, it can be seen that the major part of the cells were under apoptosis and that no significant differences between the activities of the two frutalin forms were observed. In fact, the results showed that for both lectins the percentage of apoptosis was close to 100 at $24 \mathrm{~h}$.

3.5. Interaction between Each Frutalin Form and HeLa Cells. The localisation of $\mathrm{n}$-frutalin and $\mathrm{r}$-frutalin in HeLa cells was detected by fluorescence confocal microscopy. For that, both lectins were previously labelled with FITC. One hour 
after being incubated with HeLa cells at $37^{\circ} \mathrm{C}$, both $\mathrm{n}$ frutalin and $r$-frutalin were completely internalised into these cells. Figure 6 shows representative projections for the cellular localisation of each frutalin form. As it can be seen in the fluorescence images, $r$-frutalin and $n$-frutalin were both detected around and inside HeLa nucleus (Figure 6). Nevertheless, $\mathrm{n}$-frutalin was predominantly localised in the perinuclear region, while $r$-frutalin was more concentrated in the nucleus. $\mathrm{N}$-frutalin staining was not uniform but in a dot-like manner indicating vesicular accumulation, either in perinuclear or nuclear localisation, while r-frutalin staining was more uniform. HeLa cells did not show any autofluorescence (not shown). These results suggest that the final cellular localisation of frutalin is the nucleus.

\section{Discussion}

The effects of frutalin, the $\alpha$-D-galactose-binding lectin from A. incisa, on HeLa cervical cancer cells growth were investigated for the first time.

Frutalin was demonstrated to possess a remarkable antiproliferative effect on HeLa cells. This effect was irreversible as well as time and dose dependent. MTS results showed that $\mathrm{n}$-frutalin strongly suppressed the growth of these cells at the higher concentrations tested $\left(\mathrm{IC}_{50}, 24 \mathrm{~h}\right.$ $\sim 100 \mu \mathrm{g} / \mathrm{mL}$ ). Moreover, the recombinant form of frutalin produced in $P$. pastoris yielded identical magnitude of cytotoxicity on HeLa cells to that shown by the native form, at similar concentrations (Figure 1). Upon lectins addition, serious visible cellular morphology changes were observed (Figure 6), possibly as a result of cell stress [18]. LIVE/DEAD assay proved that the antiproliferative effect of both frutalin forms was due to the induction of cell death (Figure 3). The cell death mechanism was found to be apoptosis, as indicated by genomic DNA profiling and TUNEL assay (Figures 4 and $5)$.

Plant lectins have been described to attach to cancer cells membrane or even to be internalised and located in different cellular compartments. ConA (ConcanavalinCanavalia ensiformis agglutinin, mannose/glucose-binding lectin) bound to mice hepatoma cell membrane glycoproteins (ML- $1_{4 a}$ cells) and then showed to internalise and preferentially stand onto the mitochondria [21]. WGA (wheat germ agglutinin-Triticum vulgaris, $N$-acetyl-D-glucosamine, and sialic acid-binding lectin) was internalised and located within acid compartments (such as lysosomes and transGolgi complex) of human prostate cancer cells DU-145 at $37^{\circ} \mathrm{C}$, while at $4^{\circ} \mathrm{C}$ it bound to the cells membrane, and no internalisation was observed [7]. Similar results were obtained for the interaction of artocarpin (or KM+, Artocarpus integrifolia mannose-binding lectin), mornigaM (Morus nigra mannose-binding lectin), and ConA with Jurkat $\mathrm{T}$ leukemia cells [22]. At $4^{\circ} \mathrm{C}$, these lectins only interacted with the cells membrane, but at $37^{\circ} \mathrm{C}$ they were internalised. In this work, $\mathrm{n}$-frutalin and $\mathrm{r}$-frutalin were completely internalised into HeLa cells after $1 \mathrm{~h}$ of incubation at $37^{\circ} \mathrm{C}$. Moreover, n-frutalin was observed mostly around the nucleus (accumulating in the perinuclear region) and $r$-frutalin inside the nucleus (Figure 6). Perinuclear aggregations of internalised lectins in malignant cells have already been described in other studies with lectins from fungal origin [23-25]. For instance, the fungal XCL lectin (Xerocomus chrysenteron) $(70 \mu \mathrm{g} / \mathrm{mL})$ accumulated in the perinuclear region of HeLa cells $4 \mathrm{~h}$ after incubation [24]. Nuclear localisation in HeLa cells has also been recently reported for another lectin from fungal origin (AALAgrocybe aegerita lectin) [25]. Six hours after having been applied to HeLa cells, AAL $(50 \mu \mathrm{g} / \mathrm{mL})$ was mainly attached to the cell membrane or dispersed in the cytoplasm, while a small part was around the nucleus or inside the nucleus. AAL was predominantly aggregated around the nucleus or inside the nucleus only after 24 and $36 \mathrm{~h}$, respectively. The two frutalin forms were detected around or inside HeLa nucleus in much less time than XCL and AAL lectins. Frutalin is the first lectin from plant origin reported to have nuclear localisation. This result suggests that frutalin internalisation may be distinct from the other above-mentioned plant lectins (ConA, WGA, KM+, and mornigaM). The early detection of frutalin inside HeLa nucleus indicates that frutalin apoptosis-inducing activity might be linked with its nuclear localisation, like what occurred with the fungal lectin AAL [25]. However, this hypothesis needs further confirmation. In addition, the uptake of $\mathrm{n}$-frutalin and $\mathrm{r}$ frutalin by the HeLa cells explains their irreversible cytotoxic effect.

In the present work, the native form and the recombinant form of frutalin caused identical cytotoxic effects on HeLa cells. However, it should be noted that n-frutalin and $\mathrm{r}$-frutalin have different molecular properties and, consequently, different biological activities (see Table 1). The high affinity of frutalin for galactose residues depends on the correct excision of a linker tetrapeptide between frutalin $\alpha$ and $\beta$ chains [15]. However, in the P. pastoris expression system this linker was not cleaved, resulting in a frutalin form with a lower carbohydrate-binding affinity. Nevertheless, carbohydrate-binding affinity did not compromise the cytotoxic activity of r-frutalin on HeLa cells; otherwise, higher concentrations of this lectin would have been needed to achieve the same magnitude of cytotoxicity obtained for $\mathrm{n}$-frutalin. This data is consistent with the effect of native jacalin (galactose-binding lectin isolated from jackfruit-A. integrifolia) and recombinant jacalin (produced in Escherichia coli) on the proliferation of two human cancer cell lines [18]. Recombinant jacalin showed similar magnitude of cytotoxic responses to native jacalin on A431 epidermoid carcinoma cells (cytotoxic inhibition) and HT29 colorectal carcinoma cells (noncytotoxic inhibition), although it has presented less sugar-binding affinity. Further work must be conducted to elucidate the relevance of the carbohydrate-binding properties of frutalin on HeLa cells response.

This work also highlights the feasibility of using recombinant expression systems in the preparation of biologically active pure lectin samples for biomedical purposes. In the case of frutalin, the recombinant form presents very important advantages over the native form. The extraction of frutalin from plant seeds is a time-consuming process and typically results in a heterogeneous mixture of different 
natural isoforms, which may have distinct cytotoxic activities. For example, WGA isoforms, distinguishable only by a few amino acid differences, interacted differently with leukemic cells and presented different cytoagglutinating and cytotoxic activities [26]. As r-frutalin has a defined amino acid sequence, its biological properties are more effective; that is, the reproducibility of results between different frutalin stocks is assured. Moreover, frutalin can be easily produced and purified at large scale in the $P$. pastoris expression system in a relatively much shorter period of time, comparing to the original system.

\section{Conclusions}

In this work, the effects of the frutalin lectin, obtained from its natural origin and from a recombinant expression system, on HeLa cells growth were studied. The results demonstrated that both lectins, native frutalin and recombinant frutalin, have similar irreversible cytotoxic effects on HeLa cells, by inducing cell apoptosis and inhibiting cell proliferation, in spite of their biomolecular differences. Moreover, the two frutalin forms were showed to have nuclear migration activity on these cancer cells. The effects of frutalin, and more specifically recombinant frutalin, deserve to be studied on several malignant cell lines to evaluate its potential as an anticancer agent.

\section{Acknowledgments}

Carla Oliveira was supported by the fellowship SFRH/BD/ 19099/2004 from Fundação para a Ciência e a Tecnologia, Portugal. The authors wish to acknowledge Professor Renato Moreira (Universidade de Fortaleza, Brazil) for providing breadfruit seeds and the Instituto Gulbenkian de Ciência (Portugal) for the HeLa cell line.

\section{References}

[1] N. Sharon and H. Lis, "History of lectins: from hemagglutinins to biological recognition molecules," Glycobiology, vol. 14, no. 11, pp. 53R-62R, 2004.

[2] N. Sharon, "Lectins: past, present and future," Biochemical Society Transactions, vol. 36, no. 6, pp. 1457-1460, 2008.

[3] E. G. De Mejia and V. I. Prisecaru, "Lectins as bioactive plant proteins: a potential in cancer treatment," Critical Reviews in Food Science and Nutrition, vol. 45, no. 6, pp. 425-445, 2005.

[4] B. Liu, H. J. Bian, and J. K. Bao, "Plant lectins: potential antineoplastic drugs from bench to clinic," Cancer Letters, vol. 287, no. 1, pp. 1-12, 2010.

[5] A. Pusztai, S. Bardocz, and S. W. B. Ewen, "Uses of plant lectins in bioscience and biomedicine," Frontiers in Bioscience, vol. 13, no. 3, pp. 1130-1140, 2008.

[6] H. Y. Lei and C. P. Chang, "Lectin of Concanavalin A as an anti-hepatoma therapeutic agent," Journal of Biomedical Science, vol. 16, no. 1, article 10, 2009.

[7] F. Gabor, U. Klausegger, and M. Wirth, "The Interaction between wheat germ agglutinin and other plant lectins with prostate cancer cells Du-145," International Journal of Pharmaceutics, vol. 221, no. 1-2, pp. 35-47, 2001.
[8] M. O. Hengartner, "The biochemistry of apoptosis," Nature, vol. 407, no. 6805, pp. 770-776, 2000.

[9] B. Levine and D. J. Klionsky, "Development by self-diges-tion: molecular mechanisms and biological functions of autophagy," Developmental Cell, vol. 6, no. 4, pp. 463-477, 2004.

[10] Q. Yan, Y. Li, Z. Jiang, Y. Sun, L. Zhu, and Z. Ding, "Anti-proliferation and apoptosis of human tumor cell lines by a lectin (AMML) of Astragalus mongholicus," Phytomedicine, vol. 16, no. 6-7, pp. 586-593, 2009.

[11] R. A. Moreira, C. C. Castelo-Branco, A. C. O. Monteiro, R. O. Tavares, and L. M. Beltramini, "Isolation and partial characterization of a lectin from Artocarpus incisa L. seeds," Phytochemistry, vol. 47, no. 7, pp. 1183-1188, 1998.

[12] A. C. Brando-Lima, R. F. Saldanha-Gama, M. G. Henriques, A. C. Monteiro-Moreira, R. A. Moreira, and C. Barja-Fidalgo, "Frutalin, a galactose-binding lectin, induces chemotaxis and rearrangement of actin cytoskeleton in human neutrophils: involvement of tyrosine kinase and phosphoinositide 3kinase," Toxicology and Applied Pharmacology, vol. 208, no. 2, pp. 145-154, 2005.

[13] A. C. Brando-Lima, R. F. Saldanha-Gama, C. R. Pereira et al., "Involvement of phosphatidylinositol-3 kinase-Akt and nuclear factor kappa-B pathways in the effect of frutalin on human lymphocyte," International Immunopharmacology, vol. 6, no. 3, pp. 465-472, 2006.

[14] C. Oliveira, S. Costa, J. A. Teixeira, and L. Domingues, "cDNA cloning and functional expression of the $\alpha$-D-galactosebinding lectin frutalin in Escherichia coli," Molecular Biotechnology, vol. 43, no. 3, pp. 212-220, 2009.

[15] C. Oliveira, W. Felix, R. A. Moreira, J. A. Teixeira, and L. Domingues, "Expression of frutalin, an $\alpha$-D-galactose-binding jacalin-related lectin, in the yeast Pichia pastoris," Protein Expression and Purification, vol. 60, no. 2, pp. 188-193, 2008.

[16] C. Oliveira, J. A. Teixeira, F. Schmitt, and L. Domingues, "A comparative study of recombinant and native frutalin binding to human prostate tissues," BMC Biotechnology, vol. 9, article 1472, p. 78, 2009.

[17] T. M. Nobre, F. J. Pavinatto, M. R. Cominetti, H. S. Selistre de-Araujo, M. E. D. Zaniquelli, and L. M. Beltramini, "The specificity of frutalin lectin using biomembrane models," Biochimica et Biophysica Acta, vol. 1798, no. 8, pp. 1547-1555, 2010.

[18] A. A. Sahasrabuddhe, N. Ahmed, and M. V. Krishnasastry, "Stress-induced phosphorylation of caveolin-1 and p38, and down-regulation of EGFr and ERK by the dietary lectin jacalin in two human carcinoma cell lines," Cell Stress and Chaperones, vol. 11, no. 2, Article ID csac. 2006.CSC-160R, pp. 135-147, 2006.

[19] C. Oliveira, Expression and production of recombinant frutalin in different expression systems and evaluation of its biomedical applications, Ph.D. thesis, University of Minho, Braga, Portugal, 2009.

[20] P. T. Campana, D. I. Moraes, A. C. O. Monteiro-Moreira, and L. M. Beltramini, "Unfolding and refolding studies of frutalin, a tetrameric D-galactose binding lectin," European Journal of Biochemistry, vol. 269, no. 3, pp. 753-758, 2002.

[21] C. P. Chang, M. C. Yang, H. S. Liu, Y. S. Lin, and H. Y. Lei, "Concanavalin A induces autophagy in hepatoma cells and has a therapeutic effect in a murine in situ hepatoma model," Hepatology, vol. 45, no. 2, pp. 286-296, 2007.

[22] H. Benoist, R. Culerrier, G. Poiroux et al., "Two structurally identical mannose-specific jacalin-related lectins display different effects on human $\mathrm{T}$ lymphocyte activation and cell 
death," Journal of Leukocyte Biology, vol. 86, no. 1, pp. 103114, 2009.

[23] L. G. Yu, D. G. Fernig, M. R. H. White et al., "Edible mushroom (Agaricus bisporus) lectin, which reversibly inhibits epithelial cell proliferation, blocks nuclear localization sequence-dependent nuclear protein import," Journal of Biological Chemistry, vol. 274, no. 8, pp. 4890-4899, 1999.

[24] F. Francis, C. Marty-Detraves, R. Poincloux, L. Baricault, D. Fournier, and L. Paquereau, "Fungal lectin, XCL, is internalized via clathrin-dependent endocytosis and facilitates uptake of other molecules," European Journal of Cell Biology, vol. 82, no. 10, pp. 515-522, 2003.

[25] Y. Liang, L. Feng, X. Tong et al., "Importance of nuclear localization for the apoptosis-induced activity of a fungal galectin AAL (Agrocybe aegerita lectin)," Biochemical and Biophysical Research Communications, vol. 386, no. 3, pp. 437442, 2009.

[26] H. Ohba, R. Bakalova, and M. Muraki, "Cytoagglutination and cytotoxicity of wheat germ agglutinin isolectins against normal lymphocytes and cultured leukemic cell lines-relationship between structure and biological activity," Biochimica et Biophysica Acta, vol. 1619, no. 2, pp. 144-150, 2003. 

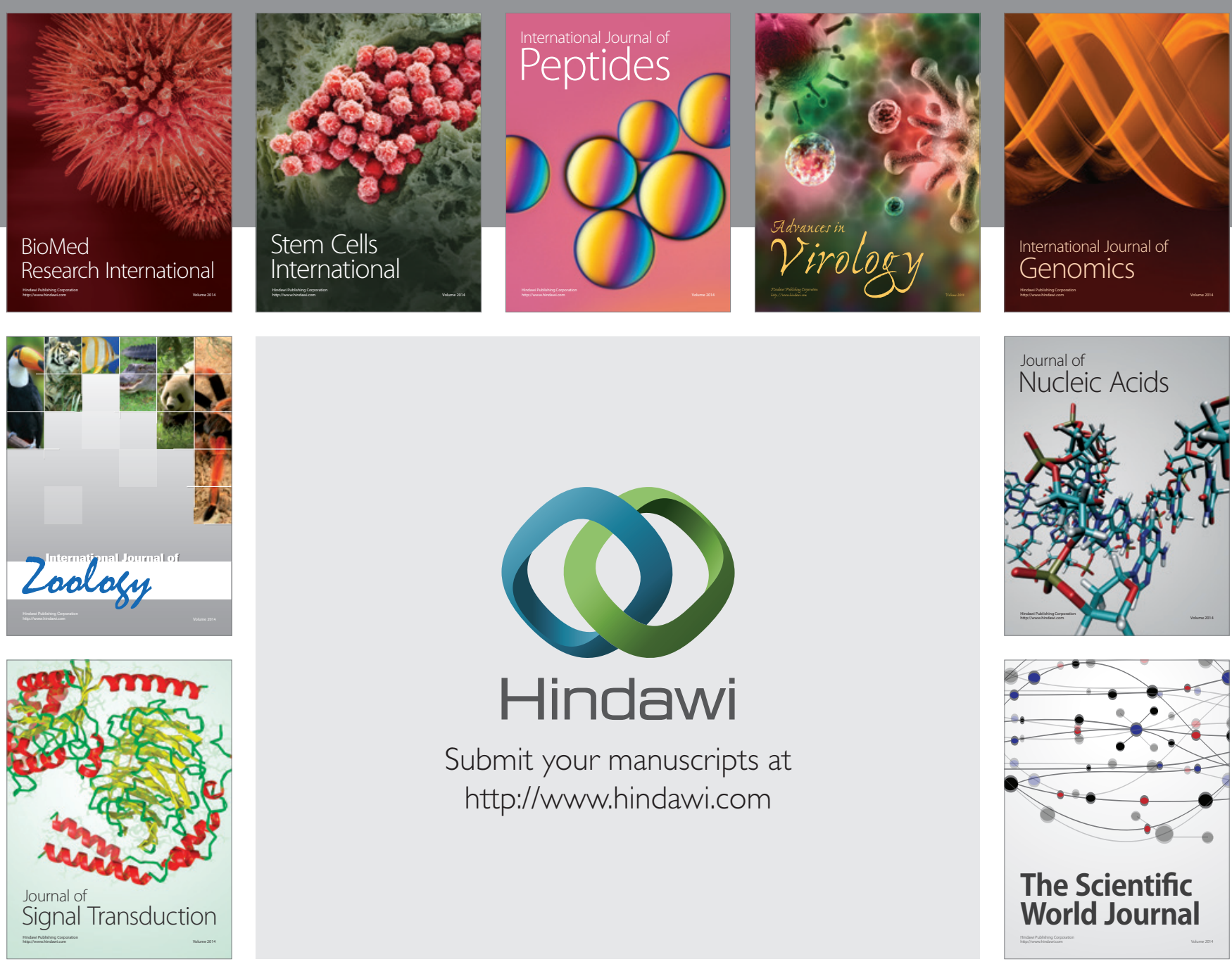

Submit your manuscripts at

http://www.hindawi.com
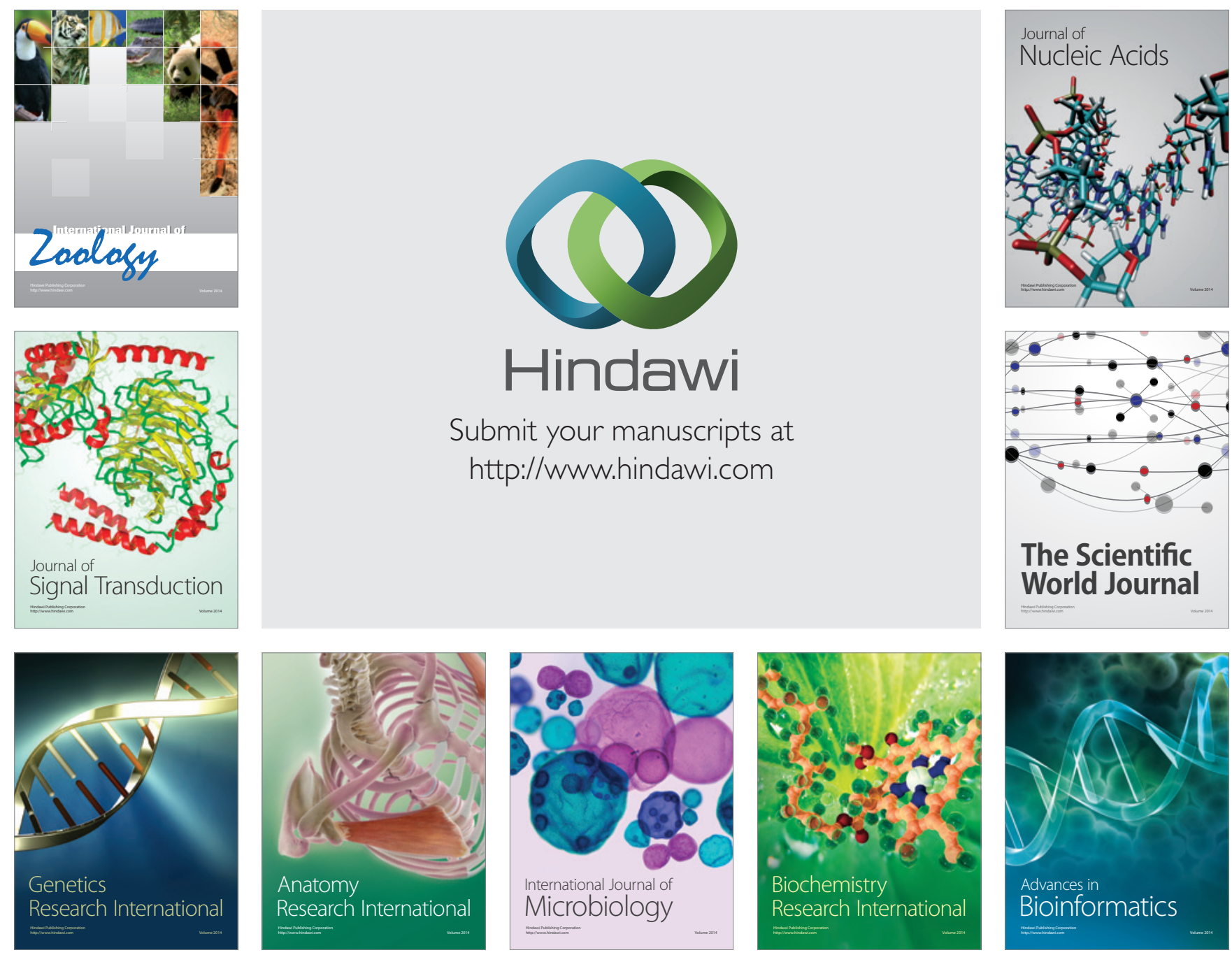

The Scientific World Journal
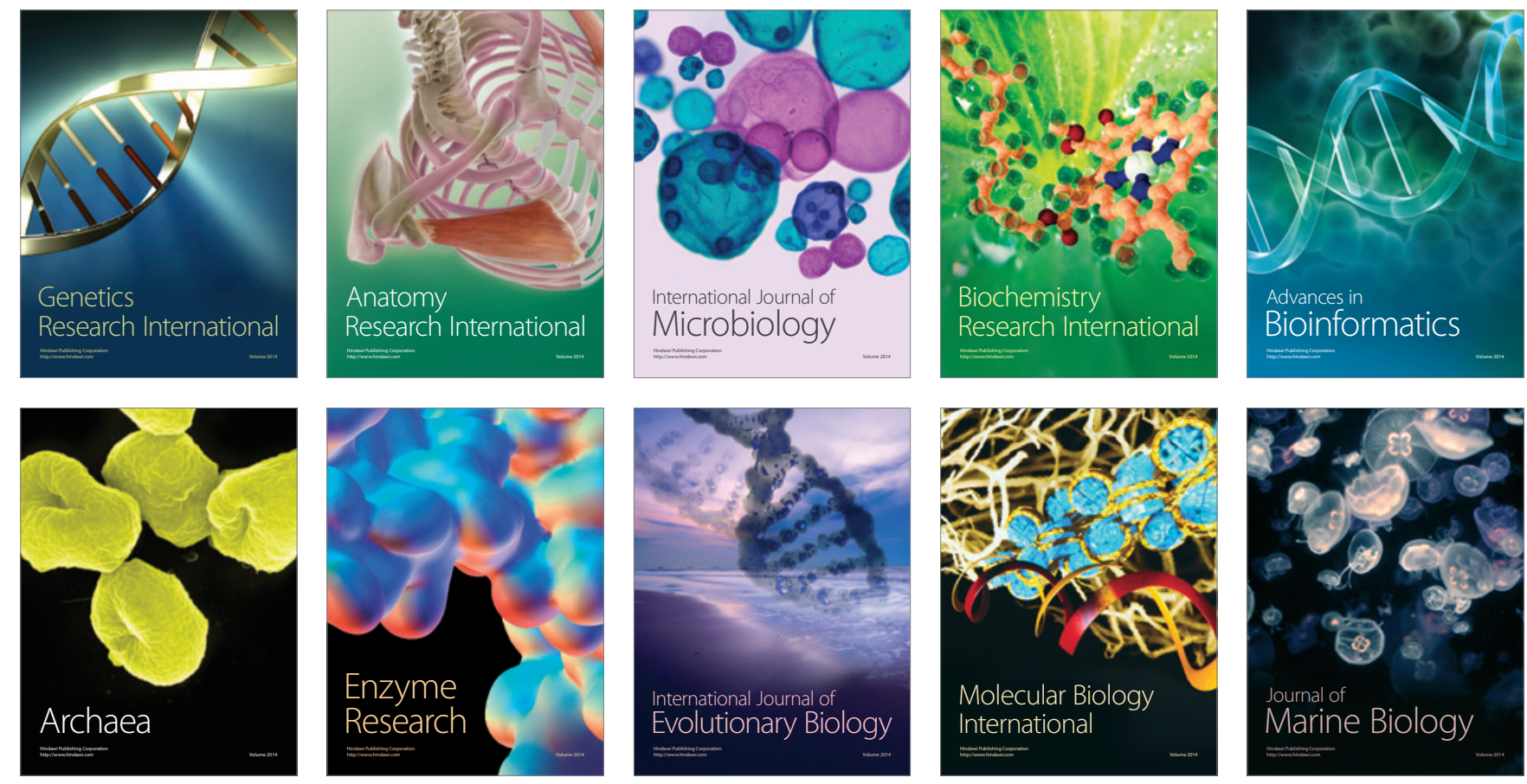